\title{
Efek Pemberian Ekstrak Etanol Buah Pare (Momordica Charantia L.) Terhadap Gambaran Histopatologi Organ Hepar Pada Tikus Putih Jantan Galur Wistar (Rattus Novergicus L.)
}

\author{
Varian Giovanni Padanga*,Edwin de Queljoea,Karlah Lifie Riani Mansaudaa \\ aProgram Studi Farmasi, Fakultas MIPA, Universitas Sam Ratulangi, Manado
}

\begin{tabular}{l} 
K A T A K U N C I \\
\hline Buah Pare \\
Gambaran Histopatologi \\
Tikus putih Jantan Galur \\
Wistar \\
Ekstrak \\
Organ Hepar
\end{tabular}

\begin{abstract}
A B S T R A K
Buah Pare (Momordica charantia L.) merupakan buah yang memiliki berbagai khasiat terapetik tapi belum diketahui efek samping apabila dikonsumsi secara berlebihan terhadap gangguan organ hepar. Tujuan penelitian ini untuk Mengetahui Pengaruh Efek Ekstrak Etanol Buah Pare pada Gambaran Histopatologi Organ hepar Tikus putih jantan galur wistar. Sampel diekstraksi menggunakan metode maserasi. Ekstrak yang diperoleh diberikan kepada 4 kelompok hewan uji dengan konsentrasi 0,100,200, dan $400 \mathrm{mg} / \mathrm{ml}$ secara berturut-turut. Setelah 50 hari, organ hepar hewan uji diambil dan dibuat preparat histopatologi. Gambaran Histopatologi menunjukan sampel organ hepar perlakuan $\mathrm{P}(100)$ dosis $100 \mathrm{mg} / \mathrm{mL}$ terlihat fokus perlemakan, untuk perlakuan $\mathrm{P}(200)$ dosis $200 \mathrm{mg} / \mathrm{mL}$ terlihat perlemakan disertai dengan terjadinya nekrosis, juga terlihat munculnya sel regeneratif. Pada $\mathrm{P}(400)$ dosis $400 \mathrm{mg} / \mathrm{mL}$ munculnya perlemakan, nekrosis, kongesti venacentralis, juga terlihat tanda sel regeneratif. Hal ini menunjukkan bahwa penggunaan ekstrak buah pare dapat menyebabkan efek negative pada jaringan sampel organ hepar galur wistar.
\end{abstract}

\author{
K E Y W OR D S \\ Bitter Melon \\ Histopathological Picture \\ Male White Rats of The \\ Wistar Strain \\ Fatty \\ Necrosis \\ Venacentral Congestion \\ Regenerative Cells.
}

\begin{abstract}
A B S T R A C T
Bitter Melon (Momordica Charantia L) is a fruit that has a various of therapeutic properties. However, Consuming an excess amount af bitter melon may have an unknown side effects towards the human's liver. The Purpose of this research is to determine the effect of histopathlogical picture of the liver in the male white rats of wistar strain. The sample was extracted by using the maceration method. The acquired extract was given to the four guinea pig with $0,100,200$, and $400 \mathrm{mg} / \mathrm{ml}$ concentration consecutively. After 50 days, the guinea pig's liver organ was taken to be tested, and histopathological preparations was made. Histopathological picture shows fats that was accumulated in the liver tissue of the liver that were given 100 $\mathrm{mg} / \mathrm{ml}$ of $\mathrm{P}(100)$. For Treatment $\mathrm{P}(200)$ dose of $200 \mathrm{mg} / \mathrm{ml}$ was seen to be accompanied by fatty necrosis, also seen the appeareance of regenerative cells. At $\mathrm{P}(400)$ dose of $400 \mathrm{mg} / \mathrm{ml}$ the appearance of fat, necrosis, venacentral Congestion, also seen signs of regenerative cells. This shows that the use of bitter melon extract may cause a side/negative effect to the sampel's hepatic tissue "galur wistar"
\end{abstract}

\begin{tabular}{l}
\hline TERSEDIA ONLINE \\
\hline 01 Agustus 2020 \\
\hline
\end{tabular}

proses penting bagi kehidupan manusia,yaitu proses penyimpanan energi, pembentukan protein dan asam empedu, pengaturan metabolisme kolesterol, dan penetralan racun/obat yang masuk dalam tubuh
Hepar (liver) merupakan organ terbesar dalam tubuh manusia.Pada organ hepar terjadi proses- 
kita.Dapat kita bayangkan akibat yang akan timbul apabila terjadi kerusakan pada hepar (A Price, 2010).

Disfungsi hepar disebabkan akibat kerusakan pada sel-sel parenkim hepar yang bisa secara langsung disebabkan oleh penyakit primer atau secara tidak langsung disebabkan oleh obstruksi aliran empedu atau gangguan sirkulasi hepatik.Proses perjalanan penyakit yang berkembang menjadi disfungsi hepatoseluler dapat disebabkan oleh penyebab menular (infectious agent), seperti bakteria serta virus, dan oleh keadaan anoksida, kelainan metabolik, toksin serta obatobatan, defisiensi nutrisi, dan keadaan hipersensitifitas (J.Corwin dan Elisabeth, 2009).

Buah Pare (Momordica chartia L.) adalah buah yang sering kita temukan di Indonesia memiliki keunikan, yaitu bentuknya yang berbintil dan rasanya sangat pahit, namun dibalik rasa pahitnya itu ternyata buah pare sangat kaya akan khasiat. Buah pare memiliki zat bermanfaat, diantaranya karantin, hidroksitriptamin, glikosida kukurbitasin, Polipeptide$P$ insulin (polipeptida yang mirip dengan insulin) yang memiliki komponen yang menyerupai sulfonilurea (Obat Diabetes paling tua), vitamin A, B dan C. Buah pare memiliki rasa pahit yang disebabkan oleh glikosida kukurbitasin, maka sebagian masyarakat kurang berminat untuk mengkonsumsi buah pare (Widayanti, 2013).

Dalam pengobatan tradisional, tanaman pare (Momordica charantia L) memberikan andil yang cukup besar bagi masyarakat. Selain kandungan gizinya yang tinggi, tanaman pare juga mengandung khasiat sebagai obat, sehingga sering dimanfaatkan sebagai bahan ramuan jamu. Di India, seluruh bagian tanaman pare dipakai sebagai obat, mulai dari akar, daun, buah, dan bijinya. Akarnya dipakai untuk mengobati penyakit mata, daunnya untuk memperlancar buang air besar, kulit terbakar, obat cacing, memperbanyak air susu ibu, menambah nafsu makan dan sebagai obat luar untuk menyuburkan rambut. Buahnya dipakai untuk pencuci darah, anti diabetes, asma, dan rematik. Di Indonesia, secara turun-temurun, tanaman pare banyak dimanfaatkan untuk mengobati beberapa penyakit, seperti diabetes, luka, dan penyakit infeksi lainnya. Tanaman pare juga dimanfaatkan sebagai anti virus, untuk mengobati penyakit hepatitis, demam, dan campak. Pengaruh ekstrak buah tanaman pare sebagai anti kanker, telah diteliti di Universitas Meiji, Jepang. Berdasarkan hasil penelitian tersebut, ekstrak buah tanaman pare sebanyak 0,5\% yang dimasukkan kedalam minuman tikus mampu menghambat perkembangan tumor pada kelenjar susu (mamae) (Tati, 2004)

Hepar (liver) merupakan organ terbesar dalam tubuh manusia.Pada organ hepar terjadi prosesproses penting bagi kehidupan manusia,yaitu proses penyimpanan energi, pembentukan protein dan asam empedu, pengaturan metabolisme kolesterol, dan penetralan racun/obat yang masuk dalam tubuh kita.Dapat kita bayangkan akibat yang akan timbul apabila terjadi kerusakan pada hepar (A Price, 2010).
Disfungsi hepar disebabkan akibat kerusakan pada sel-sel parenkim hepar yang bisa secara langsung disebabkan oleh penyakit primer atau secara tidak langsung disebabkan oleh obstruksi aliran empedu atau gangguan sirkulasi hepatik.Proses perjalanan penyakit yang berkembang menjadi disfungsi hepatoseluler dapat disebabkan oleh penyebab menular (infectious agent), seperti bakteria serta virus, dan oleh keadaan anoksida, kelainan metabolik, toksin serta obatobatan, defisiensi nutrisi, dan keadaan hipersensitifitas (J.Corwin dan Elisabeth, 2009).

Berdasarkan informasi yang diatas maka penulis terdorong untuk melakukan penelitian tentang, apakah penggunaan buah pare secara berlebihan memiliki efek samping terhadap gangguan organ hepar atau tidak melalui gambaran histopatologi, dalam rencana penelitian ini, peneliti melakukan pengujian ekstrak etanol buah pare terhadap tikus putih jantan galur wistarMaterial dan Metode.

\section{Material dan Metode \\ Alat \\ Alat yang digunakan, yaitu : Timbangan analitik, sudip, cawan petri, waterbath, oven, labu ukur, gelas ukur, gelas beker, corong gelas, pipet, batang pengaduk, hot plate, kertas saring, sarung tangan lateks, masker, botol minum, gunting blender, sonde lambung, pinset anatomi, pisau anatomi, papan bedah paraffin, jarum suntik disposible $1 \mathrm{cc}$, mikroskop, objek gelas, kaca penutup, kandang tikus putih jantan wistar, lemari pendingin, disonifikasi dan mikrotom.}

\section{Bahan}

Bahan yang digunakan, yaitu : Tikus putih jantan galur wistar (Rattus novergicus L.) 16 ekor, buah pare, etanol $96 \%$, formalin $10 \%$, aquades, Erlen Meyer, Carboxymethil Cellulose atau (CMC $1 \%$ ), pakan tikus putih jantan galur wistar yaitu pellet AD2, alluminium foil, kloroform,Xylol dan Hematoksin eosin.

\section{Pengambilan sampel buah pare}

Tahap awal dilakukan dengan pengumpulan bahan baku Sampel Buah Pare (Momordica charantiaL.) yang diambil di daerah kota Tomohon

\section{Ekstraksi Buah Pare}

Buah pare yang akan di gunakan dicuci di air mengalir terlebih dahulu sebelum diekstrak. Buah Pare ditimbang berat basah lalu dipotong kecil, kemudian dikeringkan lewat oven suhu $40^{\circ} \mathrm{C}$. Setelah kering, berat kering ditimbang, lalu di blender sampai menjadi simplisia kering, kemudian di timbang berat simplisia.setelah itu lakukan metode maserasi dengan pelarut etanol 96\% dan di biarkan selama 5 hari kemudian disaring menggunakan kertas saring dan di lakukan remaserasi dan dibiarkan selama 2 hari. Filtrat yang di peroleh dievaporasi pada suhu $40^{\circ} \mathrm{C}$ sampai di peroleh ekstrak kental

Pembuatan larutan CMC 1\% (Carboxymethil Cellulose) 
Sebanyak 1 g serbuk CMC dimasukkan ke dalam gelas beaker yang berisi aquades $50 \mathrm{~mL}$, larutan tersebut dipanaskan di waterbath sambil di aduk hingga homogen.larutan CMC lalu dipindahkan ke labu ukur $100 \mathrm{~mL}$, kemudian ditambahkan aquades hingga tanda tera.

\section{Pembuatan Suspensi Ekstrak Buah Pare sebagai Stok}

Disiapkan berbagai alat dan bahan yang akan digunakan. Ekstrak buah pare ditimbang dengan menggunakan tiga konsentrasi yaitu konsentrasi $0,18 \mathrm{~g}, 0,36 \mathrm{~g}$, dan 0,72 g. untuk pembuatan 100 $\mathrm{mL}$, kemudian dimasukan kedalam 3 labu ukur berukuran $100 \mathrm{~mL}$. masing-masing labu ukur yang sudah berisi ekstrak ditambahkan larutan CMC 1\% hingga menjadi tiap labu ukur berisi $100 \mathrm{~mL}$ Kemudian, masing-masing mulut labu ukur ditutup dengan alumunium foil dan disonifikasi selama 30 menit (hingga homogen).Suspensi ekstrak buah pare yang telah dihomogenkan dipindahkan kedalam botol berwarna gelap, ditutup dan disimpan di dalam lemari es. Larutan ekstrak suspensi $100 \mathrm{~mL}$ yang sudah jadi digunakan untuk 50 hari perlakuan

\section{Penyiapan Hewan Uj}

Penelitian ini menggunakan Tikus jantan galur wistar (Rattus novergicus L.) sebagai hewan uji yang berusia sekitar 2-3 bulan dengan bobot rata-rata 200 gram. tikus yang akan digunakan dalam penelitian harus diaklimatisasi terlebih dahulu selama kurang lebih 1 minggu sebelum perlakuan, Sampel diadaptasikan dengan tempat tinggal barunya, dengan pemberian makanan dan minuman. Perlakuan ini disamakan untuk semua tikus.Adaptasi cukup dilakukan selama 7 hari. Adaptasi ini bartujuan untuk semua objek penelitian supaya hewan coba dalam kondisi tidak stress dan dalam keadaan yang sama saat dimulai penelitian

\section{Pengelompokan Hewan Uji}

Penelitian ini menggunakan tikus putih jantan galur wistar (Rattus novergicus L.) sebagai hewan uji menjadi 4 kelompok dimana setiap kelompok terdiri dari 3 ekor tikus putih jantan galur wistar (Rattus novergicus L.) yang dipelihara dalam kandang berbahan plastic dan ditutup dengan kawat kasa dan diberi pakan berupa pellet.

1. Kelompok 1 sebagai kontrol negatif (tanpa perlakuan)

2. Kelompok 2 sebagai kelompok yang akan diberikan perlakuan ekstrak buah pare dengan dosis $100 \mathrm{mg} / \mathrm{ml}$,

3. Kelompok 3 sebagai kelompok yang diberikan perlakuan ekstrak buah pare dengan dosis 200 $\mathrm{mg} / \mathrm{ml}$

4. Kelompok 4 sebagai kelompok yang diberikan perlakuan ekstrak buah pare dengan dosis 400 $\mathrm{mg} / \mathrm{ml}$

\section{Dosis Perlakuan}

Pemberian ekstrak dilakukan selama 50 hari. Perlakuan yang digunakan adalah kontrol (tidak diberi ekstrak) dan yang diberi ekstrak buah pare (Momordica Charantia.L) dengan 3 dosis yang berbeda - beda yaitu $100 \mathrm{mg} 200 \mathrm{mg}$, dan $400 \mathrm{mg}$.
Berikut ini tabel konversi dosis hewan percobaan (Laurence and Bacharach, 1964; Sari, 2013).

\section{Perlakuan Hewan Uji}

Ekstrak buah pare diberikan secara oral dengan menggunakan sonde dengan dispo $1 \mathrm{~mL}$ yang dimasukan kedalam mulut secara perlahan-lahan untuk menghindari terjadinya refluks muntah. Hewan uji sebelum diberi perlakuan dipuasakan atau tidak diberi makan dan minum terlebih dahulu selama kurang lebih 6 jam. Hewan uji yang terdiri dari 4 kelompok diberikan perlakuan yang berbeda-beda. Kelompok 2, 3 dan 4 diberikan perlakuan sesuai dosis masing-masing kelompok yaitu 0,0018 $\mathrm{g} /$ tikus/hari sebanyak $1 \mathrm{~mL}, 0,0036 \mathrm{~g} /$ tikus/hari sebanyak $1 \mathrm{~mL}$, dan 0,0072 g/tikus/hari sebanyak 1 $\mathrm{mL}$.setiap hari sebanyak $1 \mathrm{~mL}$, sedangkan kelompok 1 hanya diberikan pakan biasa berupa pellet atau pakan tikus

\section{Pengambilan Jaringan Tikus Putih Jantan}

Langkah pertama tikus dianastesi menggunakan kloroformdengan cara memasukkan tikus wistar ke dalam wadah tertutup kemudian diamati sampai pada tingkatpembiusan yang cukup dalam. Setelah tikus tidak sadar kemudian tikus dikeluarkan dari dalam wadah dan selanjutnya dilakukan pembedahan dengan cara fiksasi setiap anggota gerak tikus dengan jarum pentol.Tikus dibedah kemudian diambil organ hepar dan di simpan pada wadah botol kecil yang berisi formalin $10 \%$.

\section{Pemeriksaan Laboratorium Histopatolog}

\section{a. Pemrosesan jaringan}

Sampel jaringan diproses di lab histopatologi. Jaringan hepar direndam dalam alkohol masingmasing sebanyak 3 kali selama 1 jam untuk proses dehidrasi. Pada proses clearing, direndam xylol sebanyak 3 kali masing-masing selama 1 jam. Infiltrasi dalam paraffin cair dengan suhu $\pm 60^{\circ} \mathrm{C}$ kemudian dibiarkan selama 24 jam. Pembuatan cetakan dengan cara jaringan ditempatkan dalam cetakan berukuran $1,5 \mathrm{~cm} \times 1,5 \mathrm{~cm}$ kemudian paraffin dituangkan dalam cetakan lalu dikeringakan sehingga terbentuk blok. Jaringan dipotong menggunakan mikrotom dengan ketebalan 5-6 mikron.Potongan-potongan jaringan tersebut diletakkan dalam air bersuhu $\pm 45^{\circ} \mathrm{C}$ sehingga potongan-potongan jaringan tersebut mengembang. Jaringan yang telah berada pada gelas objek dikeringkan dengan menggunakan tissue/kertas saring dengan cara menekan pada bagian atasnya.

b. Pewarnaan jaringan

Deparafinisasi, celupkan dalam xylol selama 10 menit. Rehidrasi, celupkan pada alcohol 95\% selama 3 menit, alcohol 70\% selama 3 menit dan air selama 3 menit,kemudian ditiriskan. Pewarnaan jaringan dilakukan beberapa tahap yaitu pertama, celupkan pada Hematoksin Eosin Gill selama 3 menit.Kedua, Cuci dengan air mengalir selama 3 menit.Ketiga, celupkan dalam eosin selama 1 menit dan keringkan.Keempat, cuci dalam alkohol 95\% selama 3 menit dan keringkan.Kelima, Celupkan dalam xylol selama 5 menit. 
Tetesi sediaan dengan menggunakan perekat entelan, lalu ditutup dengan deck glass dari arah satu sisi agar tidak ada gelembung udara.Sediaan kemudian diperiksa di bawah mikroskop.

c. Pembacaan hasil

Sediaan dievaluasi menggunakan mikroskop cahaya untuk melihat gambaran histopatologi dari organ hepar tikus. Dilakukan pemotretan pada bagian yang perlu untuk kepentingan dokumentasi.

\section{Analisis data}

Data yang dikumpulkan dalam penelitian ini adalah data primer hasilpengamatan gambaran histopatologi hepar tikus Wistar dari kelompok perlakuan yangdibandingkan dengan kelompok control.

\section{Hasil dan Pembahasan}

Bagian tanaman yang digunakan hanya bagian dalam buah pare(Momordica charantia L) yang diambil di kota Tomohon, Sulawesi utara

Proses ekstraksi simplisia buah pare diekstraksi dengan metode maserasi. Simplisia yang digunakan sebesar $200 \mathrm{~g}$ dan dimasukkan kedalam tabung Erlenmeyer,Filtrat yang di peroleh di evaporasi dengan suhu $40^{\circ} \mathrm{C}$ lalu menghasilkan ekstrak kental sebanyak 49,2 g. Pemilihan metode maserasi dikarenakan maserasi adalah metode pemisahan senyawa dengan cara perendaman menggunakan pelarut etanol pada temperature ruangan. Proses maserasi sangat menguntungkan dalam isolasi senyawa bahan alam karena selain murah dan mudah dilakukan, dengan perendaman sampel tumbuhan akan terjadi pemecahan dinding dan membran sel akibat perbedaan tekanan antara di dalam dan di luar sel, sehingga metabolit sekunder yang ada di dalam sitoplasma akan terlarut dalam pelarut (Pamolango, 2016).

Hewan Uji yang digunakan sebanyak 12 ekor tikus putih jantan, tikus putih jantan digunakan karena tikus jantan tidak mengalami siklus menstruasi sehingga tidak dapat mempengaruhi proses dari penelitian dalam pemberian perlakuan, sebelum diberikan perlakuan tikus putih jantan harus diaklimatisasi terlebih dahulu,proses aklimatisasi dilakukan kurang lebih selama 2 minggu. aklimatisasi adalah upaya proses penyesuaian fisiologis atau adaptasi dari suatu organisme terhadap suatu lingkungan baru yang akan dimasukinya (Smith dan Mangkoewidjojo, 1988).

Tikus Putih Jantan yang sudah diberikan perlakuan sesuai hari yang sudah ditentukan diambil sampel organ hepar tiap tikus tersebut, organ hepar diteliti karena organ hepar salah satu organ paling penting dalam tubuh untuk fungsi metabolisme dan detoksifikasi racun.Sebelum tikus dilakukan insisi peritoneum tikus lebih dahulu dianastesi dengan menggunakan kloroform, kloroform digunakan karena memiliki kemampuan bius yang cepat dan jika dibiarkan lama maka tikus tersebut akan langsung mati dan siap untuk dilakukan pembedahan. Kemudian organ disimpan di larutan formalin sebelum dibawa ke laboratorium
Histopatologi dimana akan dilakukan proses pemeriksaan. Formalin digunakan untuk penyimpanan organ hepar supaya organ yang diambil tidak terjadi proses pembusukan dan jaringan dari organ hepar tersebut tidak mati sebelu';m dilakukan proses pemeriksaan laboratorium.

Tabel.1 Hasil Mikroskopis Laboratorium Sampel Organ Hepar

\begin{tabular}{|c|c|c|}
\hline No & MIKROSKOPIS & KELOMPOK \\
\hline 1 & $\begin{array}{l}\text { Terlihat normal dan tidak ada } \\
\text { kerusakan jaringan }\end{array}$ & $\begin{array}{l}\text { Kontrol } \\
\text { (K1, K2, } \\
\text { K3) }\end{array}$ \\
\hline 2 & Fokus-fokus perlemakan $(1,2,3)$ & $\begin{array}{l}P \quad 100 \\
(1,2,3)\end{array}$ \\
\hline 3 & $\begin{array}{l}\text { Perlemakan, nekrosis,Selregenera } \\
\text { tif, }(1,2,3)\end{array}$ & $\begin{array}{l}P \quad 200 \\
(1,2,3)\end{array}$ \\
\hline 4 & $\begin{array}{ll}\text { Perlemakan, } & \text { kongesti,vena } \\
\text { centralis,fokus-fokus nekrosis,Sel }\end{array}$ & $\begin{array}{l}P \quad 400 \\
(1,2,3)\end{array}$ \\
\hline
\end{tabular}

Hasil dari laboratorium Patologi dapat dilihat digambar yang disertakan di lampiran. Dari 4 kelompok yang sudah diteliti yaitu kelompok Kontrol, Perlakuan $\mathrm{P}(100)$, Perlakuan $\mathrm{P}(200)$ dan perlakuan $\mathrm{P}(400)$. Dapat ditemukan kelompok kontrol yang hanya diberi makan dan minum gambaran histopatologinya terlihat normal dan tidak terlihat tanda tanda terjadi gangguan atau kerusakan. Gambaran dari kelompok kontrol dapat dilihat di gambar dengan pembesaran 40x di mikroskop dan pembesaran100x. Dari hasil laboratorium yang terlihat vena centralis organ hepar terlihat normal dan tidak terjadi gangguan yang signifikan. Di kelompok perlakuan $\mathrm{P}(100)$ terlihat terjadi timbulnya tanda tanda perlemakan pada organ hepar, tanda tersebut dapat terlihat dari munculnya titik titik pelebaran dalam struktur jaringan dari sampel organ hepar tersebut.Perlemakan adalah adanya lemak dalam sel-sel hepar (hepatosit).Hal ini disebabkan kegagalan metabolisme lemak di hepar yang normal, baik karena suatu kerusakan didalam sel hepar atau pengiriman lemak, asam lemak, maupun karbohidrat terhadap kapasitas sekresi lemak sel hepar. Pada perlemakan hepar yang berat, lemak hepar dapat mencapai 50-60\% dari berat hepar keseluruhan(Sherlock,2005). Gambar perlemakan tersebut dapat terlihat dengan alat mikroskop.

Di kelompok perlakuan $\mathrm{P}(200)$ juga terlihat timbulnya tanda tanda terjadinya perlemakan pada organ hepar seperti yang terlihat pada sampel hepar dengan dosis perlakuan $\mathrm{P}(100)$, di perlakuan $\mathrm{P}(200)$ terlihat timbulnya tanda tanda terjadinya nekrosis, tanda tanda nekrosis dapat terlihat di hasil lab mikroskopis dimana ketika sel tersebut sudah nekrosis maka jaringan di dalam sel tersebut akan terlihat lebih buram dari jaringan normal, hal ini di karenakan nekrosis merupakan salah satu pola dasar kematian sel. Nekrosis terjadi setelah suplai darah hilang atau setelah terpapar toksin dan ditandai dengan pembengkakan sel, denaturasi protein, dan kerusakan organel.Hal ini dapat menyebabkan disfungsi berat jaringan organ hepar 
(Kumar, et al 2007). Di perlakuan P(200) juga mulai terlihat tanda tanda terjadinya sel regeneratif.

Pada perlakuan (400) tanda tanda yang terlihat adalah timbulnya juga fokus fokus perlemakan pada sampel hepar tersebut,hal itu dikarenakan semakin besar dosis yang di berikan dalam jangka waktu yang lama maka semakin tinggi resiko terjadinya perlemakan. Pada perlakuan $\mathrm{P}(400)$ juga terlihat timbulnya nekrosis atau pola dasar kematian sel seperti yang terlihat di perlakuan $P(200)$. Di perlakuan $\mathrm{P}(400)$ juga terlihat tanda tanda sel regeneratif, dimana sel yang terlihat melakukan proses regenerasi, (regenerasi sel adalah proses pembentukan sel untuk menggantikan sel yang mati yang diatur mulai tingkat terkecil dalam sel tubuh kita(Sherwood, 2001). Sel regeneratif dapat terlihat di gambar hasil lab mikroskopis berupa bintik bintik hitam yang timbul di jaringan hepar tersebut yang bisa di lihat di lampiran. Di perlakuan $\mathrm{P}(400)$ juga terlihat kongesti pada bagian vena centralis, kongesti adalah (pembendungan darah) atau berlimpahnya darah di dalam pembuluh darah di wilayah atau region tertentu (Sloune, 2004).

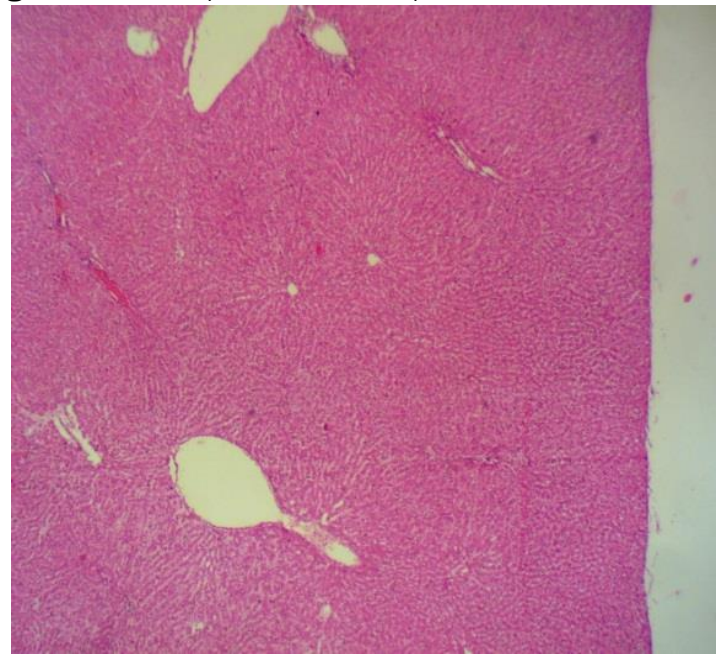

Gambar 1A. Gambaran mikroskopik (kontrol negatif) tampak hati normal dengan vena centralis pembesaran $40 x$

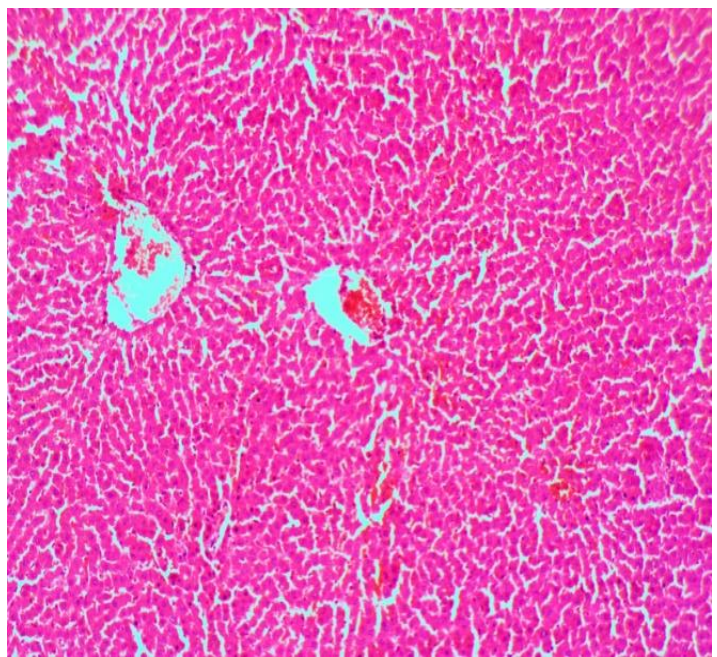

Gambar 1B. Gambaran mikroskopik (kontrol negatif) tampak hati normal dengan vena centralis pembesaran $100 x$

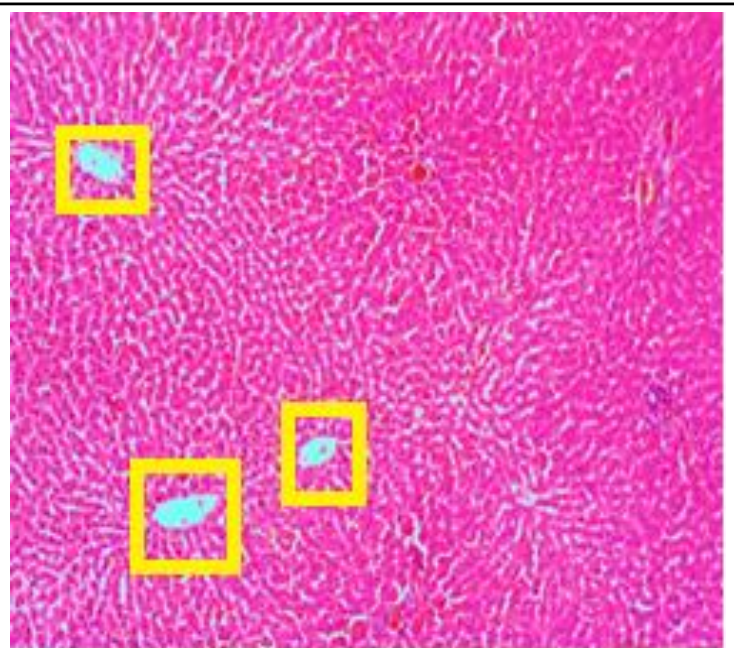

Gambar 2A.Gambaran mikroskopik P(100) tampak gambaran hati tidak normal dan terlihat terjadi perlemakan pembesaran $100 x$

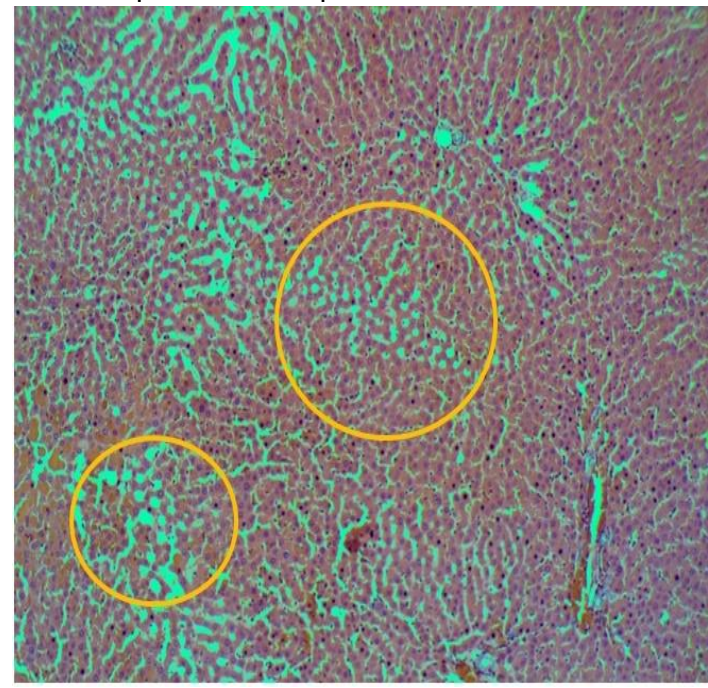

Gambar 2B. Gambaran mikroskopik P(100) gambaran hati tidak normal terlihat terjadi perlemakan pembesaran $20 \mathrm{x}$

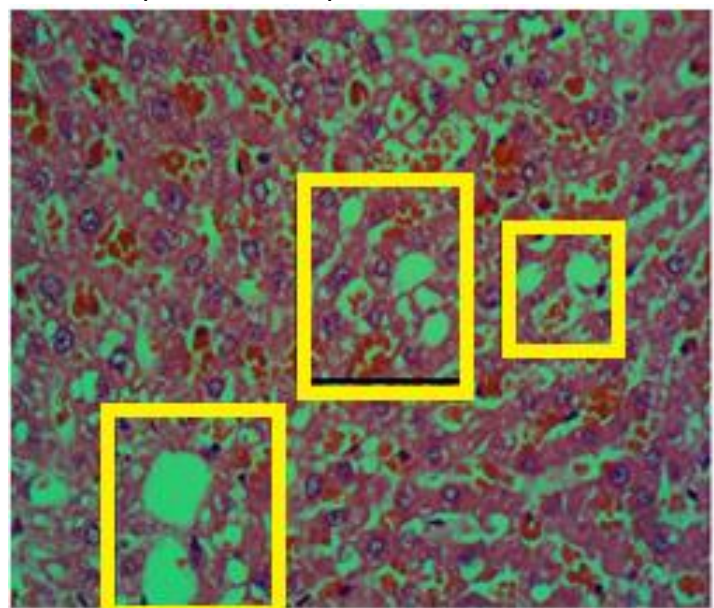

Gambar 3A.gambaran mikroskopik $\mathrm{P}(200)$ terlihat timbulnya perlemakan nekrosis terlihat sel regeneratif pembesaran $400 x$ 


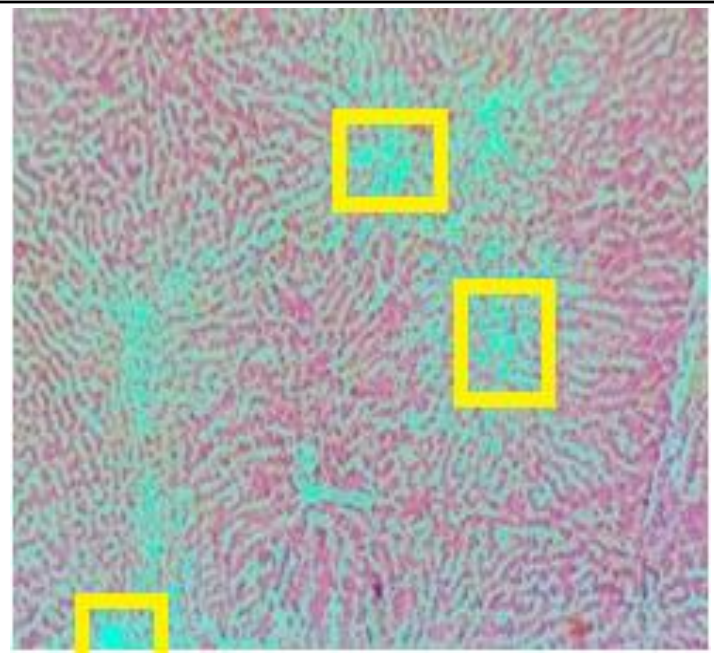

Gambar 3B.P(200) terlihat perlemakan, nekrosis dan tanda terjadi sel regeneratif pembesaran 100x

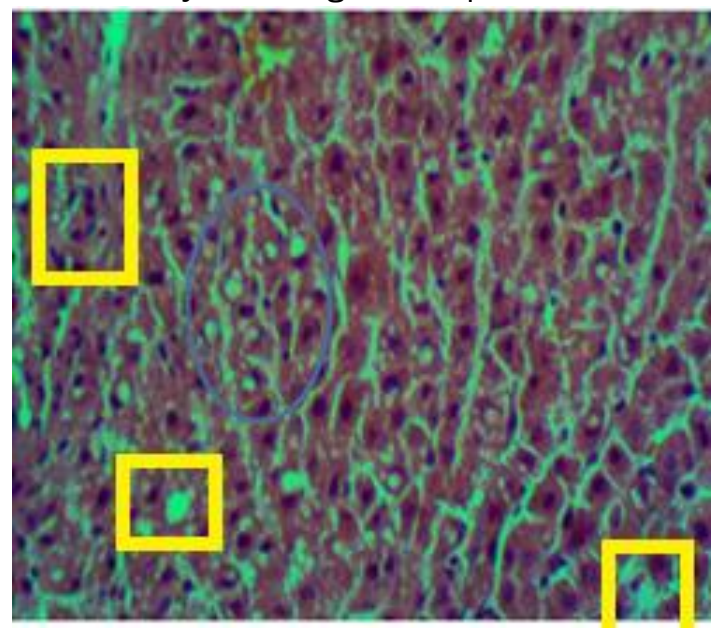

Gambar 4A.P(400) Hati tidak normal timbul fokusfokus perlemakan, sel regeneratif dan terjadi nekrosis, pembesaran 100x

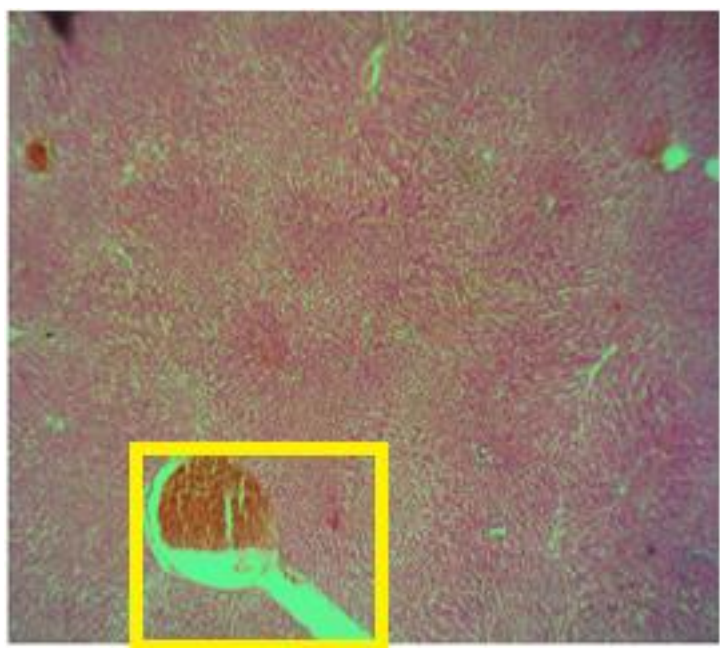

Gambar 4B.P(400) gambaran hati tidak normal terlihat kongesti vena centralis pembesaran 40x

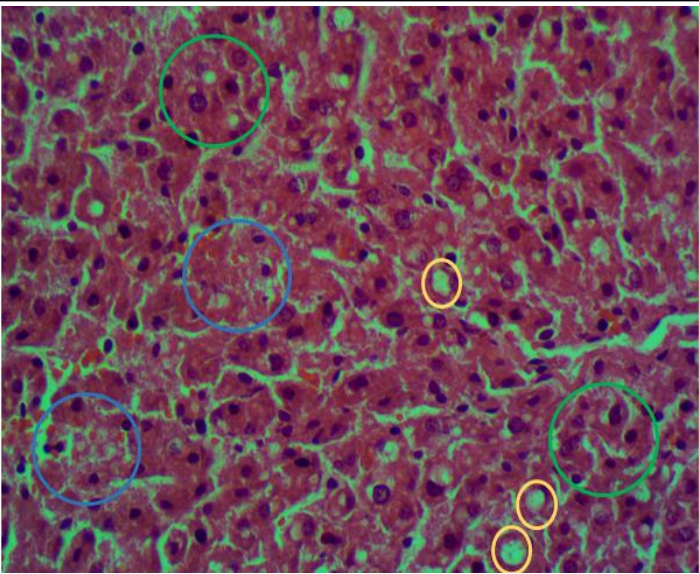

Gambar 4C.gambaran mikroskopik $\mathrm{P}(400)$ perlemakan (kuning), nekrosis (biru) dan sel regenatif (hijau) pembesaran 400x

\section{Kesimpulan}

Berdasarkan hasil penelitian yang telah dilakukan dapat disimpulkan Penggunaan Buah Pare secara berlebihan dapat Mempengaruhi Jaringan dari organ hepar. Pada perlakuan $\mathrm{P}(100)$ Tanda tanda kerusakan yang terlihat adalah timbulnya perlemakan. Pada perlakuan $\mathrm{P}(200)$ tanda tanda kerusakan yang terlihat adalah Terjadinya perlemakan dan nekrosis juga munculnya tanda sel regeneratif. Pada perlakuan $\mathrm{P}(400)$ yang terlihat adalah Timbulnya perlemakan dan terlihat juga kongesti pada vena centralis, terjadi juga nekrosis pada bagian bagian dari jaringan hepar sehingga terjadi proses regenerasi sel

\section{Daftar Pustaka}

A, Price.2010.Patofisiologi Konsep Klinis Prosesproses Penyakit.EGC. Jakarta.

Kumar, V., Cotran, R,S., dan Robbins S.L. 2007. Buku ajar Patologi. Edisi 7; ali Bahasa , Brahm U, Pendt ; Editor Bahasa Indonesia, Huriawati Hartanto, Nurwany Darmaniah, Nanda Wulandari.-ed,7Jakarta:EGC.

Laurence DR and Bacharach AL. 1964.Evaluation of Drug Activities Pharmacometricsm Academic press.London and New York. Hal. 135.

Pamolango, S. A., W. Bodhi., A. C. Wullur. 2016. Uji Fitokimia, Antioksidan, Dan Toksisitas Dari Ekstrak Daun Kentang (Solanum tuberosum) Dengan Metode 1.1-diphenyl-2-picrylhydrazyl (DPPH) dan Brine Shrimp Lethality Test (BSLT). Jurnal Ilmiah Farmasi. 5:(3) 75-84.

Sherlock, S. 2005. Penilaian Fungsi Hepar. Widya Medika. Jakarta.

Sherwood, L. 2001. Fisiologi Manusia dari Sel ke Sistem. Buku Kedokteran EGC. Jakarta.

Sloune, E. 2004.Anatomi dan Fisiologi untuk Pemula. Penerbit Buku Kedokteran EGC. Jakarta.

Smith.J.B dan S. Mangkoewidjojo. 1988. Pembiakkan dan Penggunaan Hewan Percobaan di Daerah Tropis. UI Press. Jakarta. 
Tati, S. S. Subahar, 2004, Khasiat dan manfaatPare si Pahit Pembasmi Penyakit,Agro Media Pustaka. Jakarta

Widayanti Sri 2013.Analisis Kadar Hemoglobin pada Buah Pare. USU. Medan 